CLINICAL STUDY

\title{
Melanocortin 4 receptor distribution in the human hypothalamus
}

\author{
Jacqueline E Siljee ${ }^{1}$, Unga A Unmehopa ${ }^{2}$, Andries Kalsbeek ${ }^{1,3}$, Dick F Swaab ${ }^{2}$, Eric Fliers ${ }^{1}$ and Anneke Alkemade ${ }^{1,4}$ \\ ${ }^{1}$ Department of Endocrinology and Metabolism, Academic Medical Centre, University of Amsterdam, Meibergdreef 9, Room G2-118, 1105 AZ \\ Amsterdam, The Netherlands, Departments of ${ }^{2}$ Neuropsychiatric Disorders and ${ }^{3}$ Hypothalamic Integration Mechanisms, Netherlands Institute for \\ Neuroscience, an Institute of the Royal Netherlands Academy of Arts and Science, 1105 BA Amsterdam, The Netherlands and ${ }^{4}$ Alan Turing Institute, 1311 \\ RL Almere, The Netherlands
}

(Correspondence should be addressed to J E Siljee; Email: siljeej@gmail.com)

\begin{abstract}
Objective: The melanocortin 4 receptor (MC4R) is an essential regulator of energy homeostasis and metabolism, and MC4R mutations represent the most prevalent monogenetic cause of obesity in humans known to date. Hypothalamic MC4Rs in rodents are well characterized in neuroanatomical and functional terms, but their expression pattern in the human hypothalamus is unknown.

Design and methods: To determine the topographic distribution and identity of cells expressing $M C 4 R$ mRNA in the human hypothalamus, locked nucleic acid in situ hybridization was performed on nine human postmortem hypothalami. In addition, co-expression of $M C 4 R$ with glial fibrillary acidic protein (GFAP), vasopressin/oxytocin (AVP/OXT), corticotropin-releasing hormone (CRH), neuropeptide Y (NPY), agouti-related protein (AgRP), and $\alpha$-melanocyte stimulating hormone $(\alpha-\mathrm{MSH})$ was examined. Results: Most intense MC4R mRNA expression was present in the paraventricular nucleus (PVN), the supraoptic nucleus (SON), and the nucleus basalis of Meynert. Most MC4R-positive cells in the SON also expressed AVP/OXT. Co-expression with AVP/OXT in the PVN was less abundant. We did not observe co-expression of MC4R mRNA and GFAP, CRH, NPY, AgRP, or $\alpha$-MSH. However, fiber-like staining of NPY, AgRP, and $\alpha$-MSH was found adjacent to MC4R-positive cells in the PVN.

Conclusion: Expression of MC4R mRNA in the human hypothalamus is widespread and in close approximation to endogenous MC4R binding partners AgRP and $\alpha$-MSH.
\end{abstract}

European Journal of Endocrinology 168 361-369

\section{Introduction}

The melanocortin 4 receptor (MC4R) plays an essential role in the maintenance of energy balance and is stimulated by endogenous melanocortins. MC4R has high affinity for $\alpha$-melanocyte stimulating hormone $(\alpha-\mathrm{MSH})(1)$, while the receptor is inhibited by endogenous agouti-related protein (AgRP) (2). Stimulation of MC4R decreases food intake and increases energy expenditure $(3,4)$. Less is known about the regulation of hypothalamic MC4R expression.

The important role that MC4R plays in energy homeostasis is underlined by several observations: in rodents as well as in humans, heterozygous and homozygous mutations in $M C 4 R$ lead to severe obesity. $M C 4 R$ heterozygosity accounts for $2.5-6 \%$ of all cases of morbid childhood-onset obesity $(5,6,7)$ and more than 90 obesity-associated MC4R mutations have been identified to date (8). In addition to obesity, mutations in one or both alleles of MC4R in humans are also associated with elevated fasting insulin levels, elevated blood glucose levels, enhanced linear growth, and incompletely suppressed GH secretion, as well as a reduction in blood pressure and heart rate, while a decreased prevalence of hypertension is also associated with mutations in MC4R $(9,10,11,12)$. To obtain more insight into the role of MC4R in hypothalamic melanocortin signaling, a better understanding of the underlying functional neuroanatomy is crucial.

In spite of the severe metabolic phenotype and the high prevalence of MC4R abnormalities, no distribution studies that map MC4R expression in the human brain have been published. mRNA analysis in mice and rats $(13,14)$, as well as transgenic approaches (15), has shown that MC4R expression is restricted to the CNS and many functional experiments underline the importance of MC4R function in the hypothalamus $(16,17)$. Therefore, we set out to examine for the first time the expression of the MC4R in the human hypothalamus. We chose a locked nucleic acid (LNA) in situ hybridization approach, as reliable MC4R antisera for immunohistochemistry in human brain are not available. 


\section{Materials and methods}

\section{Subjects}

Postmortem hypothalamic tissue specimens of nine individuals were studied; both men and women were included. Hypothalami were selected from subjects without any known neurological, neurodegenerative, or psychiatric disease. Clinicopathological data are described in Table 1. All brain material was obtained from The Netherlands Brain Bank at The Netherlands Institute for Neuroscience (director Dr I Huitinga) in accordance with the formal permissions for brain autopsy and for the use of human brain material and clinical information for research purposes.

\section{LNA probe}

We designed an LNA-2'-O-methyl-RNA probe specific for the human MC4R mRNA sequence. We used LNA-2'-Omethyl-RNA nucleic acid analogues because they are stable and have high hybridization affinity and have been applied in human brain successfully $(18,19)$. We used an antisense probe $5^{\prime}$-ITmUmGlCmUmGlTmGmClAmGmUlCmUmGlTmAmAmC-3' complementary to bases 478-496 of the human melanocortin 4 receptor (GenBank ref NM005912.2) and the corresponding sense probe: 5'-lGmUmUlAmCmAlGmAmClTmGmClAmCmAlGmCmAlA-3', wherein 'm'=2'-O-methylRNA (mA, mG, mC, and $\mathrm{mU}$ ) and 'l'=LNA bases. Probes were FAM tagged at the $5^{\prime}$ end and custom ordered (Ribotask, Langeskov, Denmark). Specificity of the probe was supported using the sense probe and by testing of a concentration gradient ranging from $500 \mathrm{pM}$ to $100 \mathrm{nM}$.

\section{Distribution study in situ hybridization and immunohistochemistry}

Hypothalami were dissected at autopsy and fixed in $10 \%(\mathrm{v} / \mathrm{v})$ phosphate-buffered formalin at room temperature (RT) for 24-87 days (see Table 1). After dehydration in graded ethanol series, tissues were cleared in toluene and embedded in paraffin. Coronal serial sections $(6 \mu \mathrm{m})$ were cut over the entire rostrocaudal axis. We collected every 100th section, spanning the entire hypothalamus, and mounted them on Superfrost plus slides (Menzel Glaser, Braunschweig, Germany) and subsequently dried them for at least 2 days at $37^{\circ} \mathrm{C}$. Sections were deparaffinized and rehydrated by xylene and a series of gradient alcohols followed by rinsing in PBS. Sections were pretreated for $10 \mathrm{~min}$ in the microwave at $700 \mathrm{~W}$ in PBS, which was followed by a 90-min prehybridization in a humidified chamber at $55^{\circ} \mathrm{C}$ in a hybridization mixture (hymix) with final concentrations of $50 \%(\mathrm{v} / \mathrm{v})$ deionized formamide, $600 \mathrm{mM} \mathrm{NaCl}, 10 \mathrm{mM}$ HEPES, $5 \times$ Denhardt's, $1 \mathrm{mM}$ EDTA, and $40 \mu \mathrm{g} / \mathrm{ml}$ fish sperm (Invitrogen). Probe was diluted in hybridization buffer to a final concentration of $50 \mathrm{nM}$, denatured at $95^{\circ} \mathrm{C}$ for $5 \mathrm{~min}$, and cooled on ice. Sections were hybridized in this hybridization mix overnight at $55^{\circ} \mathrm{C}$ and subsequently washed for $5 \mathrm{~min}$ each in $2 \times \mathrm{SSC}, 0.5 \times \mathrm{SSC}$, and $0.2 \times \mathrm{SSC}$ at $55^{\circ} \mathrm{C}$ and for $5 \mathrm{~min}$ in TBS at RT. Next, sections were incubated in anti-FAM-Alkaline Phosphatase (Roche) 1:4000 in SUMI (0.25\% (w/v) gelatin and $0.5 \%(\mathrm{v} / \mathrm{v})$ Triton X-100 in TBS, $\mathrm{pH} 7.6$, for $3 \mathrm{~h}$ at RT. Slides were washed $5 \mathrm{~min}$ in buffer 1 (100 mM Tris, $150 \mathrm{mM} \mathrm{NaCl}$ at $\mathrm{pH} \mathrm{7.5)} \mathrm{twice,} \mathrm{and}$ after a prewash in $100 \mathrm{mM}$ Tris- $\mathrm{HCl}, \mathrm{pH}$ 9.5, $100 \mathrm{mM}$

Table 1 Clinicopathological data.

\begin{tabular}{|c|c|c|c|c|c|c|c|c|}
\hline $\begin{array}{l}\text { NBB } \\
\text { number }\end{array}$ & $\begin{array}{c}\text { Age } \\
\text { (years) }\end{array}$ & Sex & $\begin{array}{l}\text { PMD } \\
\text { (h) }\end{array}$ & $\begin{array}{c}\text { Fix } \\
\text { (days) }\end{array}$ & BMI & Clinical diagnosis & Cause of death & Co-staining \\
\hline $1980-008$ & 35 & $\mathrm{~F}$ & 8:00 & 26 & ND & $\begin{array}{l}\text { Acute lymphoblastic } \\
\text { leukemia }\end{array}$ & Multi-organ failure & $\alpha-\mathrm{MSH}, \mathrm{AVP} / \mathrm{OXT}$ \\
\hline $1998-237$ & 38 & $\mathrm{M}$ & $10: 45$ & 37 & ND & $\begin{array}{l}\text { Wegener's disease, } \\
\text { renal failure }\end{array}$ & Multi-organ failure & \\
\hline $1998-161$ & 60 & $\mathrm{~F}$ & 8:06 & 87 & 22.9 & $\begin{array}{l}\text { Metastasized ovarian } \\
\text { cancer }\end{array}$ & Respiratory failure & $\begin{array}{l}\alpha-\mathrm{MSH} \text { AgRP } \\
\text { AVP/OXT CRH } \\
\text { GFAP }\end{array}$ \\
\hline $1998-127$ & 56 & M & $5: 25$ & 35 & 29.5 & $\begin{array}{l}\text { Cardiovascular disease, } \\
\text { type } 2 \text { diabetes, sepsis }\end{array}$ & Ventricular fibrillation & $\alpha-\mathrm{MSH}$ AgRP \\
\hline 1994-076 & 78 & M & $8: 25$ & 24 & ND & Bechterew's disease & Heart failure & \\
\hline 2001-005 & 77 & $\mathrm{~F}$ & $19: 45$ & 36 & 32 & Non-Hodgkin lymphoma & $\begin{array}{l}\text { Heart failure/ } \\
\text { multi-organ failure }\end{array}$ & $\begin{array}{l}\alpha-\mathrm{MSH} \text { AgRP } \\
\text { AVP/OXT CRH } \\
\text { NPY }\end{array}$ \\
\hline $2000-007$ & 85 & M & $15: 10$ & 35 & ND & $\begin{array}{l}\text { Recurrent myocardial } \\
\text { infarction, asthma } \\
\text { cardiale }\end{array}$ & Heart failure & $\begin{array}{l}\alpha-\mathrm{MSH} \text { AgRP CRH } \\
\text { NPY }\end{array}$ \\
\hline \multicolumn{9}{|c|}{ Co-staining study only } \\
\hline $2000-090$ & 70 & $\mathrm{M}$ & $7: 45$ & 34 & ND & $\begin{array}{l}\text { Metastasized bladder } \\
\text { carcinoma }\end{array}$ & $\begin{array}{l}\text { Respiratory insuffi- } \\
\text { ciency }\end{array}$ & $\begin{array}{l}\alpha-\mathrm{MSH}, \mathrm{AgRP}, \\
\text { AVP/OXT, GFAP }\end{array}$ \\
\hline $2001-021$ & 82 & $\mathrm{M}$ & $7: 40$ & 32 & 27.8 & Ischemic heart disease & Heart failure & $\begin{array}{l}\alpha-\mathrm{MSH}, \mathrm{AgRP}, \\
\mathrm{CRH}, \mathrm{GFAP} \\
\text { NPY }\end{array}$ \\
\hline
\end{tabular}

F, female; fix, fixation time; M, male; ND, not determined; PMD, postmortem delay. 
$\mathrm{NaCl}$, and $5 \mathrm{mM} \mathrm{MgCl}_{2}$, the color was developed using NBT-BCIP solution $(337.5 \mu \mathrm{g} / \mathrm{ml}$ NitroBlue Tetrazolium Chloride (Sigma), $175.4 \mu \mathrm{g} / \mathrm{ml}$ 5-bromo-4-chloro-3indolyl phosphate (Roche), toluidine salt, $240 \mu \mathrm{g} / \mathrm{ml}$ levamisole in $100 \mathrm{mM}$ Tris- $\mathrm{HCl}, \mathrm{pH}$ 9.5, $100 \mathrm{mM} \mathrm{NaCl}$, and $5 \mathrm{mM}_{\mathrm{MgCl}_{2}}$ ) for $3 \mathrm{~h}$ under dark conditions. Sections were then washed in distilled water, incubated in methanol (Sigma) for $5 \mathrm{~min}$, and rinsed again in distilled water. Finally, the sections were coverslipped with Aquamount (Merck) and stored at $4{ }^{\circ} \mathrm{C}$.

\section{Co-expression MC4R mRNA and immunohistochemistry}

To further identify cell types expressing the MC4R, sections were hybridized and subsequently washed twice in TBS. Sections were incubated in primary antibodies diluted in SUMI (1:100 000 rat monoclonal anti-corticotropin-releasing hormone (anti-CRH) antibody, 'PFU-83' (20), or 1:500 vasopressin/oxytocin (AVP/OXT) (Truus $(21,22)$ ) for $1 \mathrm{~h}$ at RT followed by an overnight incubation at $4{ }^{\circ} \mathrm{C}$. Alternatively, a blocking step for $1 \mathrm{~h}$ at RT in 5\% (w/v) milk in TBS preceded a primary antibody incubation in 5\% (w/v) milk-SUMI for $1 \mathrm{~h}$ at RT followed by overnight incubation at $4{ }^{\circ} \mathrm{C}$ (1:1000 neuropeptide Y (NPY) (Niepke 091188 (23)), 1:1500 AgRP (Phoenix Pharmaceuticals, Burlingame, CA, USA), 1:20 $000 \alpha$-MSH (Chemicon, Temecula, CA, USA), and 1:1000 glial fibrillary acidic protein (GFAP; Dako, Glostrup, Denmark)). Sections were washed in TBS and incubated in the appropriate biotinylated secondary antibody 1:400 in SUMI for $1 \mathrm{~h}$. After washing in TBS, sections were incubated for $1 \mathrm{~h}$ in avidin-biotin complex (1:800 in SUMI; Vector Laboratories, Burlingame, CA, USA) and subsequently rinsed in $0.2 \mathrm{M}$ glacial acetic acid. Finally, sections were incubated in glacial acetic acid buffer $(0.2 \mathrm{M}$ acetic acid and 0.2 M sodium acetate, $\mathrm{pH} 5.2$ ) with $0.015 \%$ $(\mathrm{w} / \mathrm{v})$ hydrogen peroxide and $0.5 \mathrm{mg}$ 3-amino-9-ethylcarbazole $(\mathrm{AEC}) / \mathrm{ml}$. Reaction times were determined experimentally. After stopping the reaction in water, sections were coverslipped using Aquamount (Merck) and stored at $4{ }^{\circ} \mathrm{C}$.

\section{Characteristics of primary antibodies}

All antibodies used and their immunogens are reported in Table 2. Magnocellular neurosecretary neurons of the paraventricular nucleus (PVN) and supraoptic nucleus (SON) were stained with an AVP antibody (Truus), which was raised in rabbit against AVP in its processed form, although this antibody has been reported to cross-react with OXT $(20,21)$. CRH staining specificity was supported by absence of staining using the pre-immune serum (22). In addition, staining disappeared after pre-adsorption with $\mathrm{CRH}$ and was unaffected by cross-adsorption using AVP (22). AgRP staining disappeared after pre-adsorption with AgRP and was not affected by cross-adsorption using the NPY peptide (23). The $\alpha$-MSH antibody was raised against the $\alpha$-MSH C-terminal, which is modified in $\alpha$-MSH-free acid, and absent in ACTH, minimizing cross-reaction with other POMC products. Staining was abolished after pre-adsorption with the $\alpha$-MSH peptide (24). NPY antibody specificity was previously tested by pre-immune staining and antibody pre-adsorption (23). GFAP showed exclusive glial staining. Finally, we tested omission of all primary antibodies, which did not reveal any staining.

\section{Analysis}

Distribution study Staining intensity was scored by visual inspection in a semiquantitative fashion as follows: - (no staining), $+/-$ (few positive cells showing light staining intensity), + (the majority of cells are positive and show a moderate to strong signal), ++ (the majority of cells are positive and staining intensity is high). We did not use a nuclear marker;

Table 2 Antibody characteristics.

\begin{tabular}{|c|c|c|c|}
\hline Antibody & Immunogen & Host & Manufacturer, Catalog \# \\
\hline GFAP & GFAP isolated from bovine spine & Rabbit polyclonal & DakoCytomation, Denmark, Z 0334 \\
\hline $\mathrm{CRH}$ & $\mathrm{CRH}$-bovine thyroglobulin conjugate & Rat monoclonal & $\begin{array}{l}\text { Prof. F J H Tilders (Free University of } \\
\text { Amsterdam) (Amsterdam): PFU } 83\end{array}$ \\
\hline AVP/OXT & $\begin{array}{l}\text { Synthetic peptide Cys-Tyr-Phe-GIn-Asn-Cys- } \\
\text { Pro-Arg-Gly- } \mathrm{NH}_{2} \text { (V-9879, Sigma) coupled } \\
\text { to thyroglobulin (Sigma) with glutaralde- } \\
\text { hyde (Merck) }\end{array}$ & Rabbit polyclonal & $\begin{array}{l}\text { Netherlands Institute for Neuroscience } \\
\text { (Amsterdam): \#Truus, C.P.180985 }\end{array}$ \\
\hline NPY & $\begin{array}{l}\text { Porcine NPY (1-36) (Sigma) coupled to } \\
\text { thyroglobulin (Sigma) with glutaraldehyde } \\
\text { (Merck) }\end{array}$ & Rabbit polyclonal & $\begin{array}{l}\text { Netherlands Institute for Neuroscience } \\
\text { (Amsterdam): \#Niepke C.P.261188 }\end{array}$ \\
\hline$\alpha-\mathrm{MSH}$ & $\alpha$-MSH coupled to bovine thyroglobulin & Sheep polyclonal & $\begin{array}{l}\text { Millipore, MAb Technologies, Inc., Stone } \\
\text { Mountain, GA, USA: Mab5087 }\end{array}$ \\
\hline AgRP & Human AGRP (83-132) & Rabbit polyclonal & $\begin{array}{l}\text { Phoenix Pharmaceuticals, Inc., Belmont, } \\
\text { CA, USA: \#H-003-57 }\end{array}$ \\
\hline
\end{tabular}

GFAP, glial fibrillary acidic protein; $\mathrm{CRH}$, corticotropin-releasing hormone; AVP/OXT, vasopressin/oxytocin; NPY, neuropeptide-Y; $\alpha$-MSH, $\alpha$-melanocyte stimulating hormone; AgRP, agouti-related protein. 
however, nucleoli of negative cells were visible under the light microscope. Every 100th $6 \mu \mathrm{m}$ section was scored, such that every nucleus was studied in a systematic manner covering all levels over the rostro-caudal axis. Two independent researchers assigned scores visually. Scores were compared and found to be highly similar between researchers. If scores differed, the researchers reevaluated the sections together until consensus was reached.

Co-localization study Co-localization of $M C 4 R$ and other peptides was examined in three individuals per peptide (Table 1), with three sections per individual. For co-localization studies, we sampled the central part of the nucleus. To support visual scoring of co-localization in an objective manner, we applied spectral analysis. Spectral imaging identifies colors based on their spectral characteristics, enabling extraction and visualization of the separate colored reaction products (25). Spectral analysis was performed using a CRi Nuance FX camera and software, Image pro (Media Cybernetics, Silver Spring, MD, USA), in combination with software developed at the Netherlands Institute for Neuroscience. A spectral library of the individual spectra of NBT-BCIP and AEC was made by collecting light in 'cubes' of $20 \mathrm{~nm}$ along a 200-600 $\mathrm{nm}$ spectrum, thus obtaining distinct peaks in the resulting individual light absorption graphs for the two substrates. The spectral library was then applied to image cubes (from 200 to $600 \mathrm{~nm}$ ) of the double-stained slides, which were then spectrally unmixed into individual black and white images, representing the localization of each of the reaction products. These were reverted to pseudo-colored images using the Nuance software to enhance color separation and visualization of co-localization.

\section{Results}

\section{Specificity}

We designed an LNA probe to visualize $M C 4 R$ specifically and observed the same distribution pattern using a dilution series supporting specificity (Fig. 1). Staining specificity was further supported by the absence of staining with the complementary sense probe together with the antisense probe (see insets in Fig. 2).

\section{Distribution of MC4R mRNA in the human hypothalamus}

To obtain the expression pattern of MC4R mRNA, three women and four men were studied (characteristics in Table 1). We observed a strong interindividual variation in MC4R mRNA staining intensity, which showed no obvious correlation with sex or age, although these studies were not designed to investigate such effects.
Expression of MC4R mRNA within the hypothalamus was found to be widespread (Figs 2 and 3). Contrary to the strong interindividual variation in staining intensity, staining distribution was highly similar between subjects (Table 3). Staining was most intense in the magnocellular neurons of the SON, the PVN, and in the nucleus basalis of Meynert (NBM). MC4R was also expressed - although to a lesser extent - in the medial preoptic area (MPO), the lateral septal nucleus (LS), the tuberomammillary nucleus (TMN), the bed nucleus of the stria terminalis (BST), and the mammillary nucleus (MM). Least intense staining and fewer MC4R-positive cells were found in the ventromedial hypothalamic nucleus (VMN), the dorsomedial hypothalamic nucleus (DMN), the lateral hypothalamus (LH), and the nucleus tuberalis lateralis (NTL). We found no MC4R expression in the suprachiasmatic nucleus $(\mathrm{SCN})$, infundibular nucleus (IFN; the human equivalent of the arcuate nucleus), or in the medial septal nucleus (MS). The sexually dimorphic nucleus (SDN) and diagonal band of Broca (DBB) were clearly labeled in one patient (NBB number 1998-161), but not in others, for which we found no clear explanation.
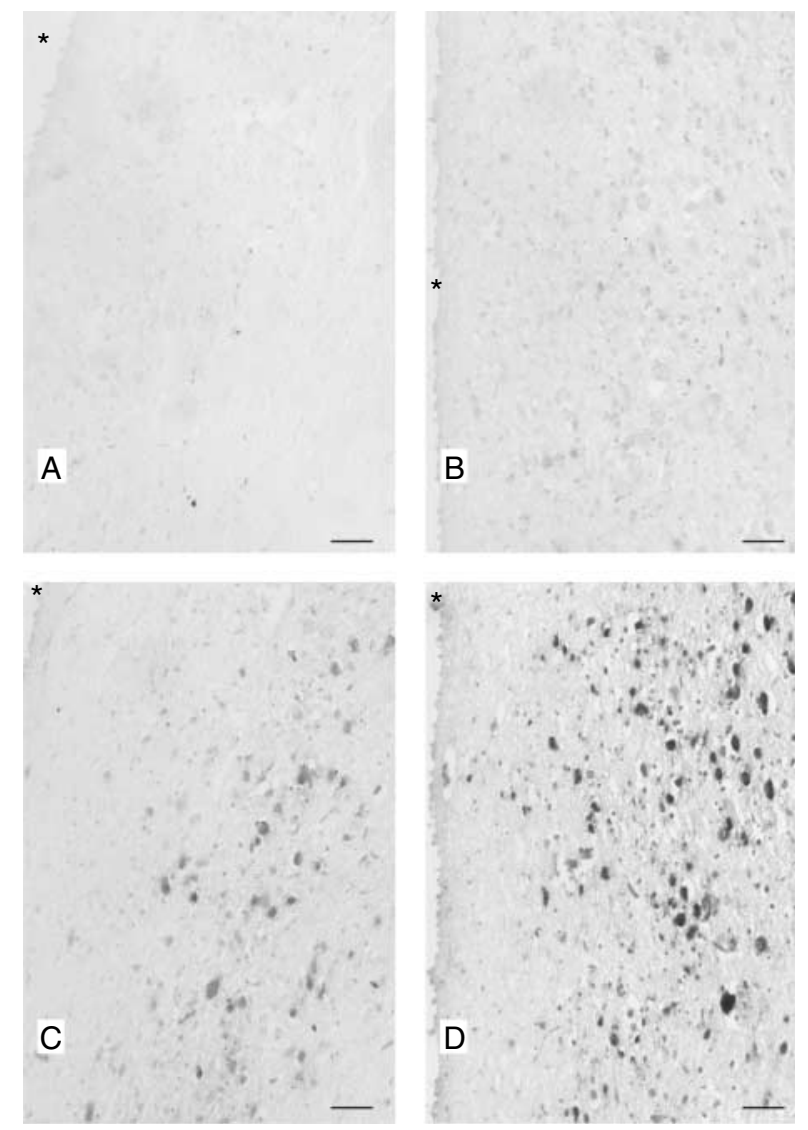

Figure $1 \mathrm{MC} 4 \mathrm{R}$ probe concentration range. (A) $0.5 \mathrm{nM}$ antisense probe in PVN of patient 2000-007. (B) $10 \mathrm{nM}$ antisense probe in PVN of patient 2000-007. (C) $50 \mathrm{nM}$ antisense probe in PVN of patient 2000-007. (D) $100 \mathrm{nM}$ antisense probe in PVN of patient 2000-007. Scale bar represents $50 \mu \mathrm{M}$; *third ventricle. 


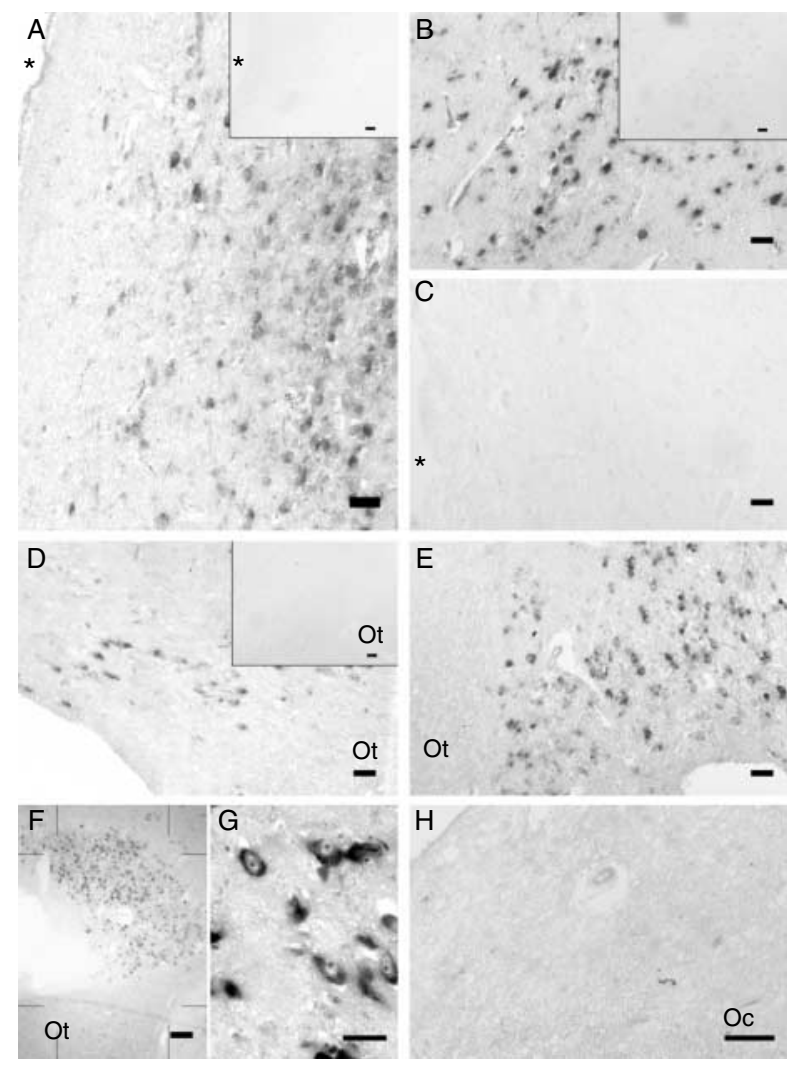

Figure 2 Representative images of $M C 4 R$ mRNA expression in the human hypothalamus. (A) Paraventricular nucleus (sense control in inset) shows intense staining (patient \# 2000-007), as does the (B) nucleus basalis of Meynert (sense control in inset) (patient \# 1998-127). (C) Infundibular nucleus is devoid of staining (patient \# 2000-007). (D) Ventromedial supraoptic nucleus (SON) with (sense control in inset) (patient \# 1980-008) shows lower staining intensity than (E) the dorsolateral SON (patient \# 1980-008). (F) Low magnification of SON (patient \# 1998-161). (G) High magnification of staining of neurons in the dorsolateral SON (patient \# 1998-161). (H) No MC4R-positive cells in the suprachiasmatic nucleus (patient \# 1998-161). Probe concentration 50 nM. Scale bar represents $50 \mu \mathrm{m}$. Ot, optic tract; Oc, optic chiasm; *third ventricle.

\section{Co-expression of MC4R mRNA with GFAP, $A V P / O X T$, CRH, AgRP, $\alpha$-MSH, or NPY}

To clarify the identity of smaller MC4R-positive cells of the hypothalamus, we examined GFAP and MC4R co-expression throughout the hypothalami of three patients (NBB \# 1998-161, 2000-090 and 2001-021) and found no GFAP overlap (Fig. 4A).

Co-expression of MC4R and CRH was studied in three subjects (a man (NBB \# 1998-237), a pre-menopausal woman (NBB \#1980-008), and a postmenopausal woman (NBB \# 1998-161) (Table 1)). CRH expression in parvocellular neurons has been reported in the human PVN and BST (26), but we did not find co-expression of $\mathrm{CRH}$ and $M C 4 \mathrm{R}$ in either nucleus (Fig. 4B).

We observed intense MC4R expression in the magnocellular neurons of the SON and PVN, which are known to express AVP and OXT (27). Within the SON, we found more magnocellular neurons positive for $M C 4 R$, with much darker staining, in the dorsolateral compared with the ventromedial part. The size of these neurons indicates that these are neurosecretory neurons, which was confirmed by co-localization with an antibody raised against AVP/OXT. Thus, we found that in the dorsolateral SON, the majority of MC4R-positive magnocellular neurons express AVP/OXT, while approximately half of the AVP/OXT-expressing cells are MC4R positive (Fig. 4C). Overlap with AVP/OXT-positive neurons in the PVN, however, was much more limited.

$\mathrm{AgRP}$ and $\alpha-\mathrm{MSH}$ are endogenous ligands of the MC4R, acting as an inverse agonist and an agonist respectively. Innervation of the human PVN by neurons containing these peptides has been established $(23,28)$. We therefore set out to examine whether these neuropeptides are indeed in close proximity of cells that are positive for MC4R mRNA in the PVN. With antibodies directed against the two neuropeptides, we found staining in close juxtaposition of MC4R-positive cells in the PVN (Fig. 4D and E), but no co-localization.

NPY, like AgRP and $\alpha$-MSH, shows a dense immunostaining in the PVN (23). In this study, we found intense NPY staining in the vicinity of MC4R-positive neurons in the PVN (Fig. 4F), but no co-localization of MC4R and NPY.



Figure 3 Schematic representation of melanocortin 4 receptor expression in the human hypothalamus. Left panel is at the rostral and right panel at the caudal level of the hypothalamus. Dark gray coloring indicates areas showing intense staining. Light gray areas indicate less intense staining. III, third ventricle; $A C$, anterior commissure; BST, bed nucleus of the stria terminalis; DMN, dorsomedial hypothalamic nucleus; FO, fornix; IFN, infundibular nucleus; LS, lateral septum; LV, lateral ventricle; NBM, nucleus basalis of Meynert; NTL, nucleus tuberalis lateralis; OC, optic chiasm; OT, optic tract; PVN, paraventricular nucleus; SCN, suprachiasmatic nucleus; SON, supraoptic nucleus; TMN, tuberomammillary nucleus; VMN, ventromedial hypothalamic nucleus. 
Table 3 Distribution of MC4R mRNA in the human hypothalamus.

\begin{tabular}{lc}
\hline Preoptic region & \\
SONvm & + \\
SONdm & ++ \\
SCN & - \\
PVN & ++ \\
MPO & + \\
NBM & ++ \\
Septum & \\
LS & + \\
MS & - \\
Tuberal region & \\
VMH & $+/-$ \\
DMH & $+/-$ \\
LH & $+/-$ \\
INF & - \\
TMN & + \\
BST & + \\
NTL & $+/-$ \\
Mammillary region & \\
MM & + \\
MML & + \\
\hline
\end{tabular}

SONvm, supraoptic nucleus, ventromedial part; SONdm, supraoptic nucleus, dorsolateral part; SCN, suprachiasmatic nucleus; PVN, paraventricular nucleus; MPO, medial preoptic area; NBM, nucleus basalis of Meynert; LS, lateral septal nucleus; MS, medial septal nucleus; VMH, ventromedial nucleus; DMH, dorsomedial hypothalamic nucleus; LH, lateral hypothalamic area; INF, infundibular nucleus; TMN, tuberomammillary hypothalamic nucleus; BST, bed nucleus of the stria terminalis; NTL, nucleus tuberalis lateralis; MM, mammillary nucleus; MML, medial mammillary nucleus, lateral part. - , no staining; $+/-$, some cells have light staining; + , most cells are positive and show a moderate-strong signal; ++ , most to all cells are positive and staining is intense.

\section{Discussion}

By examining mRNA expression in postmortem brain material, using LNA-2'-O-methyl-RNA-ISH, we are the first to describe the cellular $M C 4 R$ expression and widespread distribution in the human hypothalamus.

\section{Distribution of MC4R mRNA}

As $M C 4 R$ mutations lead to similar phenotypes in mice and humans, we expected and found the MC4R mRNA expression pattern to be similar to that described in rodents (29), although some differences were present. We found high levels of MC4R mRNA in the PVN, which is in agreement with Mc4r expression in the PVN of rodents $(14,15)$. Also, the SON was a site of high expression, as reported previously in rats, but not in mice (17). MC4R in the PVN is important for eating behavior, but the function of $M C 4 R$ expression in the SON is unknown at present. MC4R was absent in the human IFN and SCN. In mice and rats, however, low expression levels of Mc4r were reported in the arcuate nucleus. No Mc4r expression was reported in the SCN of mice (15), while in rats either high levels (13) or a complete absence has been reported (14).

We have previously investigated the effects of possible confounders on the expression levels of hypothalamic mRNAs and proteins and found no effects of postmortem delay, fixation duration, age, or sex (30, 31, 32, 33, 34). Although MC4R expression levels in this study may have been affected by metabolic factors, premortem illness, as well as cause of death in our studies, as has been shown to be the case with NPY and TRH expression levels $(23,30)$, it is highly unlikely that the distribution pattern of the MC4R is altered by disease, as this pattern was similar in all subjects included in our study.

Whether the interindividual differences in staining intensity we observed in this study are related to BMI is interesting to contemplate. Also, although casual observation may be interpreted to suggest an inverse relationship between staining intensity and BMI in the four individuals with known BMI, the present experimental design does not allow us to draw any conclusions on the relationship between $M C 4 R$ expression and BMI, especially not in view of possible nonlinear relations between neuropeptide expression and BMI as we described previously (34). To uncover a possible relationship between $M C 4 R$ expression and BMI, a similar experimental setup is required as we have published previously (34), which lies beyond the scope of these studies, but which will be the aim of our future studies.

In the LH, VMN, and DMN, we found lower levels of MC4R mRNA compared with the PVN or SON, which is

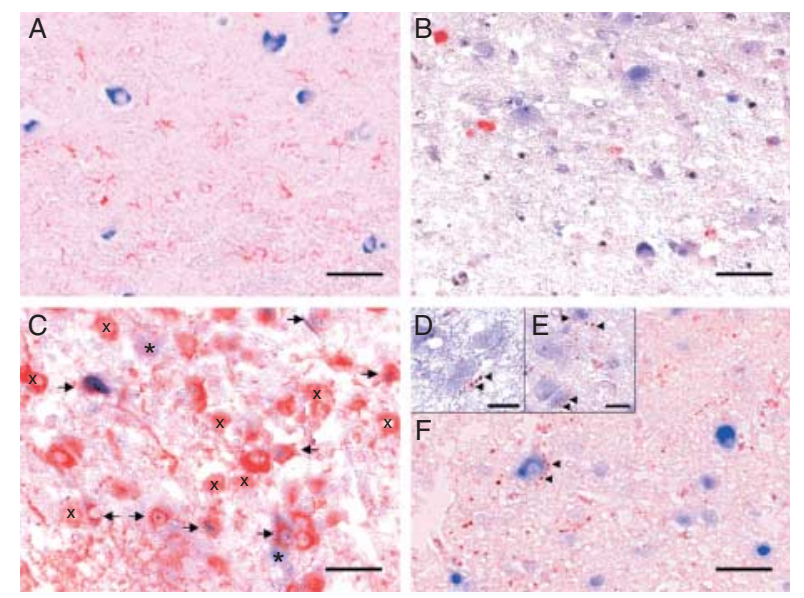

Figure 4 Representative images of $M C 4 R$ mRNA in relation to glial fibrillary acidic protein (GFAP), corticotropin-releasing hormone $(\mathrm{CRH})$, vasopressin/oxytocin (AVP/OXT), agouti-related Protein (AgRP), $\alpha$-melanocyte stimulating hormone $(\alpha-M S H)$, and neuropeptide $Y$ (NPY) in the human hypothalamus. (A) GFAP (red) spindles and MC4R-positive neurons (blue) do not show overlap (patient \# 1998-161, bed nucleus of the stria terminalis).

(B) $\mathrm{CRH}$ - (red cells) and MC4R-expression (blue) do not overlap (image of the paraventricular nucleus (PVN)) (patient \# 2000-007). (C) AVP/OXT (red) and MC4R (blue) in supraoptic nucleus do overlap (arrows), or are only positive for AVP/OXT (*), or MC4R (x) (patient \# 2000-090). (D) AgRP (red) (patient \# 2000-090, PVN),

(E) $\alpha-M S H$ (red) (patient \# 1998-161, PVN), and (F) NPY (red) can be found in close proximity (arrowheads) to MC4R-positive neurons (blue) (patient \# 2001-021, PVN). Scale bars represent $50 \mu \mathrm{m}$. 
consistent with findings in rodents (17). These nuclei are important sites for the integration of energy, glucose, and insulin homeostatic signals, and these systems become unbalanced when MC4R function is reduced (10).

The human NBM has been extensively studied in view of its role in aging and Alzheimer's disease (35). The function of MC4Rs in the NBM is currently unknown, but as we observed the highest expression levels within each patient in this particular nucleus, this will be an interesting topic for future research.

In conclusion, we found the distribution of $M C 4 R$ mRNA-expressing cells between human, rats, and mice to be largely in agreement. This observation may assist in translating the large body of rodent data on MC4R to humans.

\section{MC4R and co-localization with other neuropeptides}

$M C 4 R$ expression has previously been reported in primary rat astrocyte cultures derived from cortex (36), arcuate nucleus, and VMH (37). We used GFAP to identify astrocytes in the human hypothalamus but found no overlap with MC4R mRNA expression (Fig. 4). This may indicate a species difference or reflect an adaptation of cultured astrocytes to an ex vivo environment in the studies published earlier. The neuropeptidergic content of smaller MC4R-positive cells, such as those in Fig. 4A, requires further co-localization studies. Whether these cells could represent GFAP-negative astrocytes, oligodendrocytes, or perhaps microglia remains unclear.

The SON is an important source for circulating AVP (27) and showed high MC4R mRNA expression. AVP release is driven by serum osmolality, and inappropriately low plasma levels as seen in central diabetes insipidus lead to a hyperosmolar state with polydipsia and polyuria (38). Interestingly, the $M c 4 r^{K 314 X}$ mutation in the rat described by Mul et al. (39) induces polydipsia. In view of the currently reported co-localization of $\mathrm{AVP}$ and $M C 4 R$, it is tempting to hypothesize that a deficient AVP release in the $M c 4 r^{K 314 X}$ rat may be involved in the pathogenesis of the reported polydipsia.

$\mathrm{CRH}$ is mainly expressed in the parvocellular cells in hypothalamic nuclei, a cell type in which we also observed MC4R mRNA. Although AgRP has been reported in close proximity to a small percentage of CRH neurons in humans (26), and part of the CRH neurons in the rat PVN express Mc4r (40), we did not observe co-localization of $M C 4 R$ and $\mathrm{CRH}$ in the human PVN. Expression levels of $\mathrm{CRH}$, but not its neuroanatomical distribution, are influenced by gender and age (22). In these studies we have investigated both males and females varying in age, but in none of these subjects did we observe CRH and MC4R co-localization. Therefore, these factors are unlikely to explain the lack of co-localization. Other candidates including TRH, somatostatin, and GHRH remain to be investigated.

Innervation by $\alpha$-MSH, AgRP, and NPY of TRH neurons has been established in the human PVN (28). Although most TRH-positive cells in the PVN are parvocellular, TRH expression in a small number of magnocellular neurons has been described as well (41). Although TRH immunostaining has been reported earlier in picric acid/glutaraldehyde-fixed vibratome sections, it was unsuccessful in formalin-fixed material such as we used (41) and could therefore not be incorporated in this study. In view of the current observation of extensive innervation of $M C 4 R$-positive neurons by $\alpha-\mathrm{MSH}, \mathrm{AgRP}$, and NPY fibers, co-expression of TRH in these magnocellular neurons is highly likely but remains to be investigated using different tissue treatments.

\section{MC4R innervation by $\alpha$-MSH, AgRP, and NPY}

Classically, MC4R is activated by its N-terminus (basal activity) (42) and further stimulated by $\alpha$-MSH. These activations of the receptor can be undone by the binding of AgRP (2). In line with this concept, we found terminals containing the endogenous binding partners of the MC4R, i.e. $\alpha$-MSH and AgRP, in close proximity to MC4R-expressing neurons in the PVN. This strongly suggests that the functional neuroanatomy of the melanocortin signaling system in humans is similar to that of rodents.

POMC neurons that produce $\alpha$-MSH and project to the PVN express Y-receptors that enable NPY to indirectly affect MC4R activity through the production and/or release of $\alpha$-MSH by POMC neurons. However, NPY innervation directly onto the PVN in humans (43), as well as low levels of Y1- and higher levels of Y2-receptor binding sites, have been described in the PVN (44). In addition, Y5 receptor mRNA is expressed in magnocellular neurons of the PVN and SON (45), as well as in other nuclei in which we found $M C 4 R$ to be expressed. In this study, we found NPY terminals in close proximity to MC4R-expressing neurons in the PVN (Fig. 4F). In mice, green fluorescent protein under the Mc4r-promoter Y1-receptor and GFP co-localization was found in subnuclei of the PVN (46). Using the same mouse model, a strong inhibitory effect of NPY on MC4R-positive cells was measured by electrophysiology (47). NPY receptors inhibit adenylyl cyclase via activation of $G_{i}$ or $G_{o}$ proteins $(48,49,50)$, thus opposing the $\mathrm{G}_{\mathrm{a}}$ s-activation of adenylate cyclases that occurs due to MC4R stimulation. These findings could provide an additional pathway for NPY to affect melanocortin signaling, not only through POMC neurons but also directly affecting MC4R-positive neurons. Whether this regulatory system is indeed in place in the human brain is currently unknown. 


\section{Conclusions and future directions}

This study provides the anatomic distribution of MC4R mRNA in the human hypothalamus for the first time and starts to unravel the identity of MC4R-expressing neurons. Profiling the neurons that express MC4R can provide us with a deeper understanding of the mechanisms underlying the development of obesity both in patients with and without MC4R signaling defects and of other symptoms associated with MC4R mutations.

\section{Declaration of interest}

The authors declare that there is no conflict of interest that could be perceived as prejudicing the impartiality of the research reported.

\section{Funding}

J E Siljee was supported by an AMC PhD Scholarship, A Alkemade received a Veni-grant of the Netherlands Organization for Health Research and Development (grant nr 916.86.020).

\section{Author contribution statement}

E Fliers, A Alkemade, J E Siljee, and D F Swaab were involved in the study concept and design. J E Siljee and U A Unmehopa were involved in acquisition of data. J E Siljee, E Fliers, and U A Unmehopa were involved in analysis and interpretation of data. J E Siljee and A Alkemade were involved in drafting of the manuscript. A Alkemade, E Fliers, A Kalsbeek, and D F Swaab were involved in critical revision of the manuscript for important intellectual content. U A Unmehopa, J E Siljee and A Alkemade were involved in administrative, technical, and material support. A Alkemade was involved in study supervision.

\section{Acknowledgements}

The authors would like to thank Chantal Vlaskamp and Bart Fisser for excellent technical assistance and Joop van Heerikhuize and Joris Coppens for their help with spectral analysis and microscopy.

\section{References}

1 Schioth HB, Muceniece R, Larsson M \& Wikberg JE. The melanocortin $1,3,4$ or 5 receptors do not have a binding epitope for ACTH beyond the sequence of $\alpha$-MSH. Journal of Endocrinology 1997155 73-78. (doi:10.1677/joe.0.1550073)

2 Lu D, Willard D, Patel IR, Kadwell S, Overton L, Kost T, Luther M, Chen W, Woychik RP, Wilkison WO et al. Agouti protein is an antagonist of the melanocyte-stimulating-hormone receptor. Nature 1994371 799-802. (doi:10.1038/371799a0)

3 Fan W, Boston BA, Kesterson RA, Hruby VJ \& Cone RD. Role of melanocortinergic neurons in feeding and the agouti obesity syndrome. Nature 1997385 165-168. (doi:10.1038/385165a0)

4 Fan W, Voss-Andreae A, Cao WH \& Morrison SF. Regulation of thermogenesis by the central melanocortin system. Peptides 2005 26 1800-1813. (doi:10.1016/j.peptides.2004.11.033)

5 Lubrano-Berthelier C, Le Stunff C, Bougneres P \& Vaisse C. A homozygous null mutation delineates the role of the melanocortin-4 receptor in humans. Journal of Clinical Endocrinology and Metabolism 200489 2028-2032. (doi:10.1210/jc.2003-031993)

6 Lubrano-Berthelier C, Dubern B, Lacorte JM, Picard F, Shapiro A, Zhang S, Bertrais S, Hercberg S, Basdevant A, Clement K et al. Melanocortin 4 receptor mutations in a large cohort of severely obese adults: prevalence, functional classification, genotype-phenotype relationship, and lack of association with binge eating. Journal of Clinical Endocrinology and Metabolism 200691 1811-1818. (doi:10. 1210/jc.2005-1411)

7 Vaisse C, Clement K, Durand E, Hercberg S, Guy-Grand B \& Froguel P. Melanocortin-4 receptor mutations are a frequent and heterogeneous cause of morbid obesity. Journal of Clinical Investigation 2000106 253-262. (doi:10.1172/JCI9238)

8 Tao YX. The melanocortin-4 receptor: physiology, pharmacology, and pathophysiology. Endocrine Reviews 201031 506-543. (doi:10.1210/er.2009-0037)

9 Farooqi IS, Keogh JM, Yeo GS, Lank EJ, Cheetham T \& O’Rahilly S. Clinical spectrum of obesity and mutations in the melanocortin 4 receptor gene. New England Journal of Medicine $2003 \mathbf{3 4 8}$ 1085-1095. (doi:10.1056/NEJMoa022050)

10 Martinelli CE, Keogh JM, Greenfield JR, Henning E, van der Klaauw AA, Blackwood A, O'Rahilly S, Roelfsema F, CamachoHubner $\mathrm{C}$, Pijl $\mathrm{H}$ et al. Obesity due to melanocortin 4 receptor (MC4R) deficiency is associated with increased linear growth and final height, fasting hyperinsulinemia, and incompletely suppressed growth hormone secretion. Journal of Clinical Endocrinology and Metabolism 201196 E181-E188. (doi:10.1210/jc.2010-1369)

11 Greenfield JR, Miller JW, Keogh JM, Henning E, Satterwhite JH, Cameron GS, Astruc B, Mayer JP, Brage S, See TC et al. Modulation of blood pressure by central melanocortinergic pathways. New England Journal of Medicine 2009360 44-52. (doi:10.1056/ NEJMoa0803085)

12 Sayk F, Heutling D, Dodt C, Iwen KA, Wellhoner JP, Scherag S, Hinney A, Hebebrand J \& Lehnert H. Sympathetic function in human carriers of melanocortin-4 receptor gene mutations. Journal of Clinical Endocrinology and Metabolism $2010 \mathbf{9 5}$ 1998-2002. (doi:10.1210/jc.2009-2297)

13 Mountjoy KG, Mortrud MT, Low MJ, Simerly RB \& Cone RD. Localization of the melanocortin-4 receptor (MC4-R) in neuroendocrine and autonomic control circuits in the brain. Molecular Endocrinology 1994 8 1298-1308. (doi:10.1210/me.8.10.1298)

14 Kishi T, Aschkenasi CJ, Lee CE, Mountjoy KG, Saper CB \& Elmquist JK. Expression of melanocortin 4 receptor mRNA in the central nervous system of the rat. Journal of Comparative Neurology 2003457 213-235. (doi:10.1002/cne.10454)

15 Liu H, Kishi T, Roseberry AG, Cai X, Lee CE, Montez JM, Friedman JM \& Elmquist JK. Transgenic mice expressing green fluorescent protein under the control of the melanocortin-4 receptor promoter. Journal of Neuroscience 200323 7143-7154. (doi:10.1210/en.2009-0881)

16 Balthasar N, Dalgaard LT, Lee CE, Yu J, Funahashi H, Williams T, Ferreira M, Tang V, McGovern RA, Kenny CD et al. Divergence of melanocortin pathways in the control of food intake and energy expenditure. Cell 2005123 493-505. (doi:10.1016/j.cell.2005.08.035)

17 Siljee-Wong JE. Melanocortin MC4 receptor expression sites and local function. European Journal of Pharmacology $20116 \mathbf{6 6 0}$ 234-240. (doi:10.1016/j.ejphar.2010.10.104)

18 Vester B \& Wengel J. LNA (locked nucleic acid): high-affinity targeting of complementary RNA and DNA. Biochemistry 200443 13233-13241. (doi:10.1021/bi0485732)

19 Nelson PT, Baldwin DA, Kloosterman WP, Kauppinen S, Plasterk RH \& Mourelatos Z. RAKE and LNA-ISH reveal microRNA expression and localization in archival human brain. RNA 2006 12 187-191. (doi:10.1261/rna.2258506)

20 Raadsheer FC, Sluiter AA, Ravid R, Tilders FJ \& Swaab DF. Localization of corticotropin-releasing hormone (CRH) neurons in the paraventricular nucleus of the human hypothalamus; age-dependent colocalization with vasopressin. Brain Research 1993615 50-62. (doi:10.1016/0006-8993(93)91113-7)

21 van der Sluis PJ, Pool CW \& Sluiter AA. Immunochemical detection of peptides and proteins on press-blots after direct tissue gel isoelectric focusing. Electrophoresis $19889654-661$. (doi:10.1002/elps.1150091006)

22 Swaab DF, Hofman MA \& Honnebier MB. Development of vasopressin neurons in the human suprachiasmatic nucleus in relation to birth. Brain Research. Developmental Brain Research 199052 289-293. (doi:10.1016/0165-3806(90)90247-V) 
23 Goldstone AP, Unmehopa UA, Bloom SR \& Swaab DF. Hypothalamic NPY and agouti-related protein are increased in human illness but not in Prader-Willi syndrome and other obese subjects. Journal of Clinical Endocrinology and Metabolism 200287 927-937. (doi:10.1210/jc.87.2.927)

24 Elias CF, Saper CB, Maratos-Flier E, Tritos NA, Lee C, Kelly J, Tatro JB, Hoffman GE, Ollmann MM, Barsh GS et al. Chemically defined projections linking the mediobasal hypothalamus and the lateral hypothalamic area. Journal of Comparative Neurology 1998402 442-459. (doi:10.1002/(SICI)1096-9861(19981228) 402:4<442::AID-CNE2>3.0.CO;2-R)

25 Hoozemans JJ, van Haastert ES, Nijholt DA, Rozemuller AJ, Eikelenboom P \& Scheper W. The unfolded protein response is activated in pretangle neurons in Alzheimer's disease hippocampus. American Journal of Pathology 2009174 1241-1251. (doi:10.2353/ajpath.2009.080814)

26 Mihaly E, Fekete C, Lechan RM \& Liposits Z. Corticotropinreleasing hormone-synthesizing neurons of the human hypothalamus receive neuropeptide Y-immunoreactive innervation from neurons residing primarily outside the infundibular nucleus. Journal of Comparative Neurology 2002446 235-243. (doi:10.1002/cne.10193)

27 Fliers E, Swaab DF, Pool CW \& Verwer RW. The vasopressin and oxytocin neurons in the human supraoptic and paraventricular nucleus; changes with aging and in senile dementia. Brain Research 1985342 45-53. (doi:10.1016/0006-8993(85) 91351-4)

28 Mihaly E, Fekete C, Tatro JB, Liposits Z, Stopa EG \& Lechan RM. Hypophysiotropic thyrotropin-releasing hormone-synthesizing neurons in the human hypothalamus are innervated by neuropeptide Y, agouti-related protein, and $\alpha$-melanocyte-stimulating hormone. Journal of Clinical Endocrinology and Metabolism $2000 \mathbf{8 5}$ 2596-2603. (doi:10.1210/jc.85.7.2596)

29 Farooqi IS, Yeo GS, Keogh JM, Aminian S, Jebb SA, Butler G, Cheetham T \& O'Rahilly S. Dominant and recessive inheritance of morbid obesity associated with melanocortin 4 receptor deficiency. Journal of Clinical Investigation 2000106 271-279. (doi:10.1172/ JCI9397)

30 Fliers E, Guldenaar SEF, Wiersinga WM \& Swaab DF. Decreased hypothalamic thyrotropin-releasing hormone gene expression in patients with nonthyroidal illness. Journal of Clinical Endocrinology and Metabolism $1997 \mathbf{8 2} 4032-4036$. (doi:10.1210/jc.82.12.4032)

31 Fliers E, Unmehopa UA, Manniesing S, Vuijst CL, Wiersinga WM \& Swaab DF. Decreased neuropeptide Y (NPY) expression in the infundibular nucleus of patients with nonthyroidal illness. Peptides 200122 459-465. (doi:10.1016/S0196-9781(01)00341-2)

32 Alkemade A, Vuijst CL, Unmehopa UA, Bakker O, Vennström B, Wiersinga WM, Swaab DF \& Fliers E. Thyroid hormone receptor expression in the human hypothalamus and anterior pituitary. Journal of Clinical Endocrinology and Metabolism 200590 904-912. (doi:10.1210/jc.2004-0474)

33 Alkemade A, Unmehopa UA, Hessel EV, Swaab DF, Kalsbeek A \& Fliers E. Suppressor of cytokine signaling 3 in the human hypothalamus. Peptides 201235 139-142. (doi:10.1016/j.peptides. 2012.03.004)

34 Alkemade A, Yi CX, Pei L, Harakalova M, Swaab DF, la Fleur SE, Fliers E \& Kalsbeek A. AgRP and NPY expression in the human hypothalamic infundibular nucleus correlate with body mass index, whereas changes in $\alpha \mathrm{MSH}$ are related to type 2 diabetes. Journal of Clinical Endocrinology and Metabolism 201297 E925-E933. (doi:10.1210/jc.2011-3259)

35 Swaab DF \& Bao AM. (Re-)activation of neurons in aging and dementia: lessons from the hypothalamus. Experimental Gerontology 2011 46 178-184. (doi:10.1016/j.exger.2010.08.028)

36 Selkirk JV, Nottebaum LM, Lee J, Yang W, Foster AC \& Lechner SM. Identification of differential melanocortin 4 receptor agonist profiles at natively expressed receptors in rat cortical astrocytes and recombinantly expressed receptors in human embryonic kidney cells. Neuropharmacology 200752 459-466. (doi:10. 1016/j.neuropharm.2006.08.015)
37 Caruso C, Durand D, Schioth HB, Rey R, Seilicovich A \& Lasaga M. Activation of melanocortin 4 receptors reduces the inflammatory response and prevents apoptosis induced by lipopolysaccharide and interferon-gamma in astrocytes. Endocrinology $2007 \mathbf{1 4 8}$ 4918-4926. (doi:10.1210/en.2007-0366)

38 Sanmarti A, Galard R, Catalan R, Foz M \& Castellanos JM. Plasmatic arginine vasopressin levels in total and partial diabetes insipidus. Journal of Endocrinological Investigation $1985 \mathbf{8}$ 127-130.

39 Mul JD, van Boxtel R, Bergen DJ, Brans MA, Brakkee JH, Toonen PW, Garner KM, Adan RA \& Cuppen E. Melanocortin receptor 4 deficiency affects body weight regulation, grooming behavior, and substrate preference in the rat. Obesity $2012 \mathbf{2 0}$ 612-621. (doi:10.1038/oby.2011.81)

40 Lu XY, Barsh GS, Akil H \& Watson SJ. Interaction between $\alpha$-melanocyte-stimulating hormone and corticotropinreleasing hormone in the regulation of feeding and hypothalamopituitary-adrenal responses. Journal of Neuroscience 200323 7863-7872.

41 Fliers E, Noppen NW, Wiersinga WM, Visser TJ \& Swaab DF. Distribution of thyrotropin-releasing hormone (TRH)-containing cells and fibers in the human hypothalamus. Journal of Comparative Neurology 1994350 311-323. (doi:10.1002/cne.903500213)

42 Srinivasan S, Lubrano-Berthelier C, Govaerts C, Picard F, Santiago P, Conklin BR \& Vaisse C. Constitutive activity of the melanocortin- 4 receptor is maintained by its $\mathrm{N}$-terminal domain and plays a role in energy homeostasis in humans. Journal of Clinical Investigation $2004 \mathbf{1 1 4} 1158-1164$. (doi:10.1172/ JCI21927)

43 Pelletier G, Desy L, Kerkerian L \& Cote J. Immunocytochemical localization of neuropeptide Y (NPY) in the human hypothalamus. Cell and Tissue Research 1984238 203-205. (doi:10.1007/ BF00215163)

44 Jacques D, Dumont Y, Fournier A \& Quirion R. Characterization of neuropeptide $\mathrm{Y}$ receptor subtypes in the normal human brain, including the hypothalamus. Neuroscience $1997 \mathbf{7 9} 129-148$. (doi:10.1016/S0306-4522(96)00639-2)

45 Nichol KA, Morey A, Couzens MH, Shine J, Herzog H \& Cunningham AM. Conservation of expression of neuropeptide Y5 receptor between human and rat hypothalamus and limbic regions suggests an integral role in central neuroendocrine control. Journal of Neuroscience 199919 10295-10304.

46 Kishi T, Aschkenasi CJ, Choi BJ, Lopez ME, Lee CE, Liu H, Hollenberg AN, Friedman JM \& Elmquist JK. Neuropeptide Y Y1 receptor mRNA in rodent brain: distribution and colocalization with melanocortin-4 receptor. Journal of Comparative Neurology 2005482 217-243. (doi:10.1002/cne.20432)

47 Ghamari-Langroudi M, Srisai D \& Cone RD. Multinodal regulation of the arcuate/paraventricular nucleus circuit by leptin. PNAS 2011108 355-360. (doi:10.1073/pnas.1016785108)

48 Bard JA, Walker MW, Branchek TA \& Weinshank RL. Cloning and functional expression of a human Y4 subtype receptor for pancreatic polypeptide, neuropeptide Y, and peptide YY. Journal of Biological Chemistry 1995 270 26762-26765. (doi:10.1074/jbc. 270.45.26762)

49 Gerald C, Walker MW, Vaysse PJ, He C, Branchek TA \& Weinshank RL. Expression cloning and pharmacological characterization of a human hippocampal neuropeptide Y/peptide YY Y2 receptor subtype. Journal of Biological Chemistry 1995270 26758-26761. (doi:10.1074/jbc.270.45.26758)

50 Herzog H, Hort YJ, Ball HJ, Hayes G, Shine J \& Selbie LA. Cloned human neuropeptide Y receptor couples to two different second messenger systems. PNAS 199289 5794-5798. (doi:10.1073/ pnas.89.13.5794)

Received 25 August 2012

Revised version received 6 November 2012

Accepted 4 December 2012 